\title{
ARTICLES
}

\section{Epithelial Defect in Prostates of Stat5a-Null Mice}

\author{
Marja T. Nevalainen, Tommi J. Ahonen, Hiroko Yamashita, \\ Varadaraj Chandrashekar, Andrzej Bartke, Philip M. Grimley, Gertraud W. Robinson, \\ Lothar Hennighausen, and Hallgeir Rui
}

Department of Pathology (MTN, TJA, HY, PMG, HR), Uniformed Services University of the Health Sciences, and Laboratory of Genetics and Physiology (GWR, LH), National Institutes of Diabetes and Kidney Diseases, National Institutes of Health, Bethesda, Maryland; Department of Physiology (VC, AB), Southern Illinois University, Life Science II, Carbondale, Illinois; and Department of Anatomy (TJA), Institute of Biomedicine, University of Turku, Turku, Finland

\begin{abstract}
SUMMARY: The transcription factor Stat5a critically mediates prolactin (PRL)-induced mammary gland development and lactogenesis. PRL also stimulates growth and differentiation of prostate tissue. Specifically, hyperprolactinemia gives rise to prostate hyperplasia, and prostate size is reduced in PRL-deficient mice. We therefore investigated the importance of Stat5a for prostate development and function by examining Stat5a-null mice. The absence of Stat5a in mice was associated with a distinct prostate morphology characterized by an increased prevalence of local disorganization within acinar epithelium of ventral prostates. Affected acini were typically filled with desquamated, granular epithelial cells that had become embedded in dense, coagulated secretory material. These features were reminiscent of acinar cyst formation and degeneration frequently observed in human benign prostate hyperplasia, however, cystic changes in prostate acini of Stat5a-deficient mice were not associated with increased prostate size or morphologic hallmarks of epithelial hyperplasia. Instead, immunohistochemistry of the prostate-specific secretory marker, probasin, suggested that hypersecretory function of the epithelium could underlie local congestion and cyst formation in prostates of Stat5a-null mice. Serum testosterone and PRL levels were normal in Stat5a knockout mice, but prostate PRL receptor expression was reduced as determined by immunohistochemistry. Expression levels or activation states of other PRL signal transduction proteins, including Stat5b, Stat3, Stat1, ERK1, and ERK2 were not altered. The present study offers the first evidence for a direct role of Stat5a in the maintenance of normal tissue architecture and function of the mouse prostate. (Lab Invest 2000, 80:993-1006).
\end{abstract}

$P$ rostate growth and differentiation are regulated by male sex steroids and a range of polypeptide factors. Prolactin (PRL) is one of several polypeptide factors that exert a trophic effect on the prostate (Costello and Franklin, 1994; Reiter et al, 1995a, 1995b, 1999). PRL receptors are selectively expressed in the epithelial compartment of the prostate, and in vitro studies of long term organ cultures of prostate

Received December 28, 1999.

This work was supported by the Academy of Finland, International Agency of Research on Cancer, Turku Postgraduate School, and the National Institutes of Health Grant RO1 DK52013 (to ).

The content of this publication does not necessarily reflect the views or policies of the Department of Health and Human Services, nor does mention of trade names, commercial products, or organizations imply endorsement by the United States Government. By acceptance of this article, the publisher or recipient acknowledges the right of the United States Government to retain a nonexclusive, royalty-free license in and to any copyright covering the article.

Address reprint requests to: Dr. H. Rui, Department of Pathology, Uniformed Services University of the Health Sciences School of Medicine, Bethesda, Maryland 20814. Fax: (301) 295-1640; E-mail: hrui@usubs.mil tissue explants have demonstrated that PRL stimulates differentiation, proliferation, and survival of prostate epithelial cells (Ahonen et al, 1999; Nevalainen et al, 1991, 1997a, 1997b). PRL also has been implicated in progression of prostate cancer and development of benign hyperplasia (Janssen et al, 1996; Nakamura et al, 1990; Wennbo et al, 1997). Advanced hyperplastic enlargement of prostate was the predominant result of hyperprolactinemia in male mice overexpressing a PRL transgene (Wennbo et al, 1997). Correspondingly, targeted disruption of the PRL gene in mice led to a reduced prostate size (Steger et al, 1998). In addition, autocrine production of PRL or a PRL-like protein in prostate epithelial cells has indicated further physiologic involvement of PRL in prostate biology (Nevalainen et al, 1996, 1997a, 1997b).

Evidence from studies of mammary gland development and function has suggested that the transcription factor Stat5a is a principal mediator of PRL signal transduction (Gouilleux et al, 1994; Liu et al, 1995, 1996, 1997; Wakao et al, 1994). Stat5a-deficiency disrupted PRL signal transduction in mammary glands of female mice, causing suppression of growth and 
terminal differentiation of the lobuloalveolar compartment and blocked PRL-induced milk production (Liu et al, 1997). This phenotype was not observed in mice deficient for Stat5b (Teglund et al, 1998; Udy et al, 1997), which is structurally the closest homologue of Stat5a among members of the Stat transcription factor family (Darnell, 1997). In addition to PRL, several other polypeptide factors that activate Stat5 have been implicated in growth promotion of prostate epithelium, including epidermal growth factor, interleukin-6, and insulin-like growth factor I (Steiner, 1993; Russell et al, 1998). We therefore determined to what extent the targeted disruption of the Stat5a gene affected prostate development and morphology in mice.

We found that prostates of Stat5a-deficient mice displayed an increased rate of regional cystic degeneration and desquamation of the epithelial cells that was associated with evidence of hypersecretory function of prostate epithelium. The observations provide novel evidence of a critical role for Stat5a in the maintenance of normal prostate tissue integrity and function.

\section{Results and Discussion}

\section{Tissue Alterations in Prostates of Stat5a-Null Male Mice}

Inactivation of the Stat5a gene was associated with an increased prevalence of local disorganization of the epithelium in ventral prostates of adult mice. Affected acini were typically filled with detached, granular epithelial cells that had become embedded in dense, coagulated secretory material (Fig. 1a, c, e, and f). In contrast, prostates of wild-type mice showed only sporadic occurrence of distended acini and epithelial disorganization; instead, acini were generally well organized and regular with tall columnar secretory epithelial cells (Fig. 1b and d).

The effect of Stat5a-deficiency on prostate morphology was quantified by counting the deteriorated acini in prostate sections of Stat5a -/- and Stat5a $+/+$ mice (Fig. 2). Two groups of adult mice were examined that had comparable age distributions, with a mean age of Stat5a-null mice of 9.2 months, and a mean age of 8.8 months for wild-type mice. On average, in prostates of Stat5a-null mice, $10.6 \%$ of acini were cystic, compared with $1.0 \%$ in wild-type mice (Fig. $2 ; p<0.01$ ). Whereas acinar disorganization and shedding of the epithelial cells was detected in prostates of 12 of $17(71 \%)$ of the Stat5a-deficient mice, only 3 of $14(21 \%)$ of the wild-type mice displayed cyst formation. Furthermore, the extent of changes was more severe in affected prostates of Stat5a-null mice than in prostates of affected wildtype animals. In prostates of the wild-type mice, the mean fraction of affected acini was 4.6 (range 1.5\% to $9.8 \%$ ), whereas the mean fraction of acini with cell shedding and cyst formation in prostates of the 12 Stat5a-null mice was $15.0 \%$ (range $2.9 \%$ to $50.0 \%$ ).

The observed morphologic feature of prostates of Stat5a-null mice was reminiscent of formation micro- cysts and cystic degeneration frequently noted in benign prostate hyperplasia of human prostates (Mostofi and Price, 1973). However, the cystic changes in Stat5a-deficient mice were not associated with increase in prostate size or with morphologic hallmarks of epithelial hyperplasia, such as hypercellularity, hyperconvolution of the epithelial lining, epithelial bridging, or secondary hyperplasia with formation of "glands-within-glands" (Mostofi and Price, 1973). There also was no detectable stromal hyperplasia in prostates of Stat5a-deficient mice as determined by morphologic analysis. This was supported by equal expression of the smooth muscle marker, actin, in prostates of Stat5a-deficient mice and wildtype mice as measured by immunoblotting (Fig. 3) and by immunohistochemistry (data not shown).

\section{Evidence of Increased Secretion, but not of Altered Rates of Apoptosis or Proliferation of Epithelial Cells in Prostates of Stat5a-Null Mice}

Conceptually, congestion and cyst formation in the acini of prostates of Stat5a-null mice could be caused by an increased rate of secretion, an increased viscosity, or clogging because of an abnormal rate of epithelial desquamation. Because PRL and Stat5a prevent apoptosis and epithelial involution of the lactating mammary gland (Liu et al, 1997), and because $\mathrm{PRL}$ is an anti-apoptotic factor for rat prostate epithelium (Ahonen et al, 1999), we investigated whether increased epithelial apoptosis occurred in prostates of mice lacking Stat5a. Detachment-induced apoptosis, or anoikis, is a distinctive form of cell death described for epithelial or endothelial cell populations (Frisch and Francis, 1994; Frisch et al, 1996). In addition to examining epithelial apoptosis, we analyzed epithelial proliferation rates, because altered levels of epithelial apoptosis might be associated with compensatory changes in cell proliferation. In parallel, we investigated whether Stat5a-deficiency was associated with increased prostate secretory activity.

In situ DNA fragmentation analysis was used to detect epithelial apoptosis (Fig. 4), and immunohistochemistry for proliferating cell nuclear antigen (PCNA) was employed to assess cell proliferation (Fig. 5). Among the large number of desquamated epithelial cells within cystic acini, only a small fraction were positive by in situ end-labeling of fragmented DNA, suggesting a limited extent of ongoing apoptosis in cystic acini (Fig. 4a). Ventral prostates of androgendeprived and androgen-substituted castrated rats served as positive and negative controls, respectively (Fig. 4b and c). Similarly, epithelial regions of prostates of Stat5a-deficient mice that were not affected by cystic change showed no evidence of an increased rate of apoptosis (not shown), thus indicating that increased apoptosis was not a primary cause of cell shedding and cyst formation. Furthermore, the degree of positive immunoreactivity by anti-PCNA immunohistochemistry did not reveal any significant differences in epithelial proliferation rates in the prostates between wild-type mice (Fig. 5b) and knock-out mice 


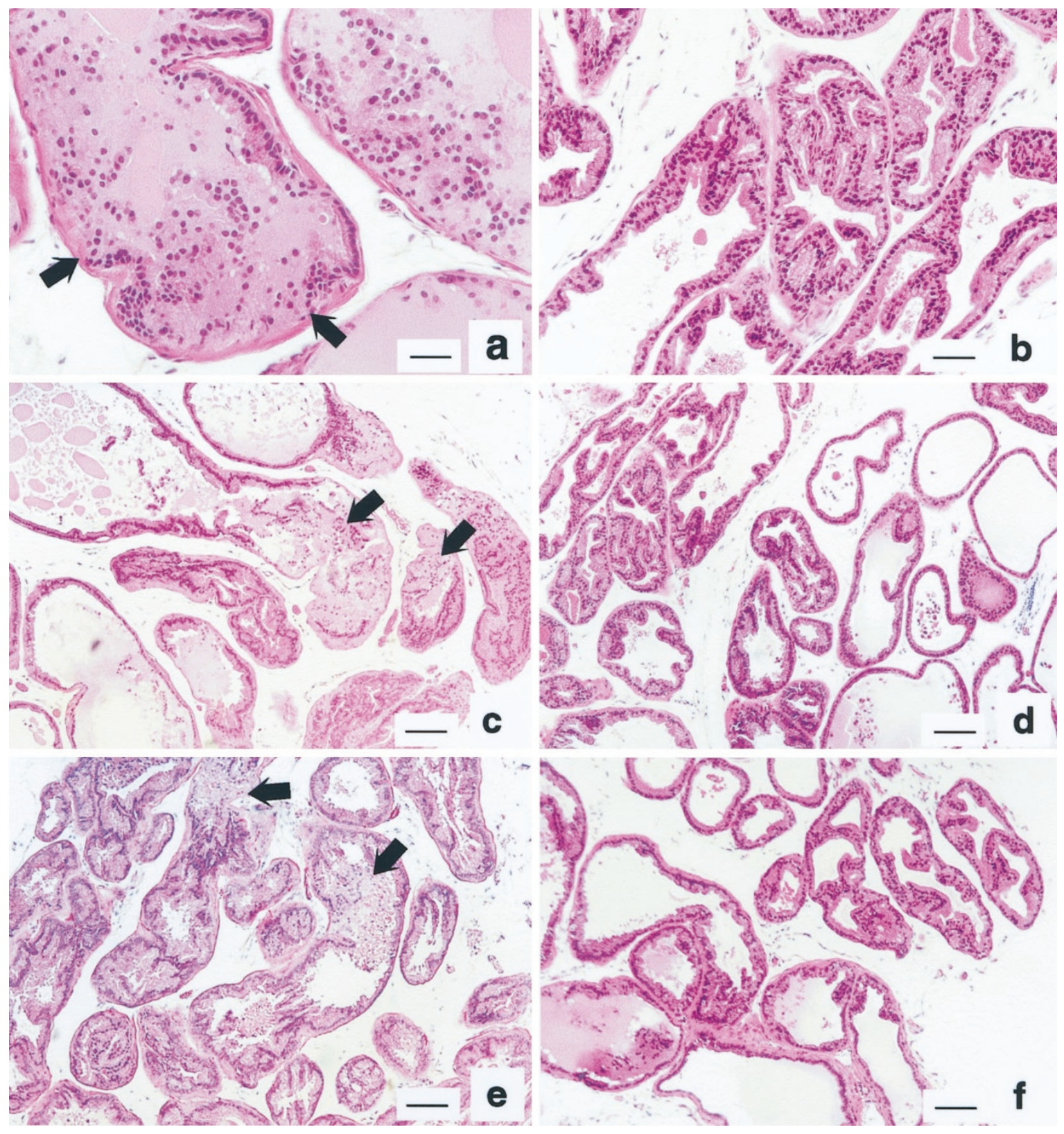

\section{Figure 1.}

Morphology of ventral prostates of Stat5a-null (a, c, e, f) and wild-type (b, d) mice. Arrows indicate affected acini filled with desquamated epithelial cells that have become embedded in dense, coagulated secretory material. Prostate acini of Stat5a-deficient mice were frequently distended and filled with secretion. In contrast, prostate acini of wild-type mice were generally well-organized and regular, with tall columnar secretory epithelial cells (b, d). a: bar $=82 \mu \mathrm{m} ; \mathrm{b}:$ bar $=47 \mu \mathrm{m}$; $c$ $\mathrm{d}, \mathrm{e}, \mathrm{f}:$ bar $=93 \mu \mathrm{m}$.

(Fig. $5 a$ and c). Counting verified that the number of PCNA-immunoreactive cells did not differ significantly between ventral prostates of wild-type $(1.45 \pm 0.26 \%)$ and Stat5a-deficient mice (1.26 $\pm 0.18 \%$ ) (Fig. 5e). Therefore, a generally increased rate of prostate epithelial proliferation did not seem to underlie the changes associated with Stat5a-deficiency. As expected, the number of PCNA-immunoreactive cells was markedly reduced in cystic areas (Fig. 5c), confirming the dysfunctional and degenerative nature of this alteration. Control antibodies showed no immunoreactivity (Fig. 5d). Collectively, these results suggested that congestion and acinar cyst formation in prostates of Stat5a-deficient mice was not caused by a generally increased epithelial cell turnover.

To evaluate the secretory function of ventral prostate epithelial cells, we used immunohistochemistry of the prostate-specific secretory protein probasin (Dodd et al, 1986). This protein is particularly highly expressed in rat dorsolateral prostate, but as indicated by immunoblotting using a specific polyclonal antiprobasin antibody, probasin was also expressed in rat and mouse ventral prostates (Fig. 6a).

In noncystic regions of prostates of Stat5a -/mice, immunohistochemistry showed a marked increase in the level of probasin immunoreactivity in 


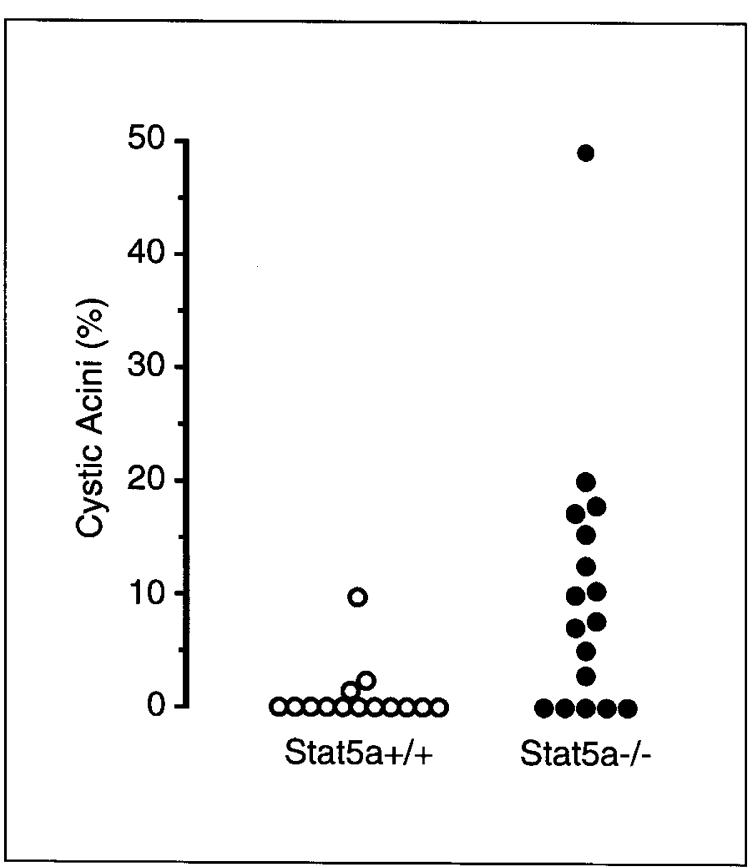

Figure 2.

Increased frequency of cystic change in prostates of Stat5a-null mice. Multiple sections of ventral prostates from adult wild-type mice ( $n=14$, open circles) and Stat5a $-/-$ mice ( $n=17$, filled circles) of comparable age range (6 to 16 months) were counted for occurrence of cystic acini. Data are expressed as percentage of cystic acini.

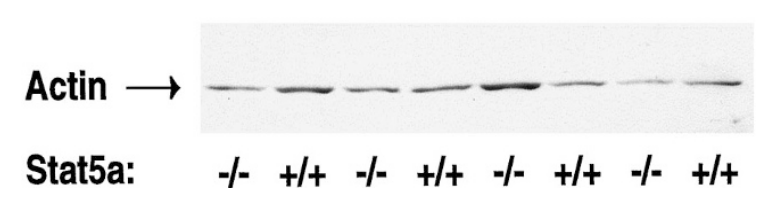

Figure 3.

Actin expression in ventral prostates of Stat5a-knockout mice. Immunoblotting of $20 \mu \mathrm{g}$ of total protein from prostate tissue homogenates using anti-actin antibody demonstrated comparable expression levels of actin in Stat5a - /$(n=4)$ and Stat5a $+/+(n=4)$ ventral prostates.

epithelial cells and in acinar lumens (Fig. 6b) when compared with wild-type mice (Fig. 6c). Control sections incubated with normal rabbit serum showed no positive reactivity, attesting to the specificity of the antiserum (Fig. 6d). However, the increased local expression of probasin within normal regions of prostates of Stat5a -/- mice detected by immunohistochemistry was not readily reflected in overall elevated probasin levels in whole tissue protein extracts, as measured by immunoblotting. This apparent inconsistency is most likely caused by the corresponding loss of probasin expression in cystic, nonfunctional regions in prostates of Stat5a -/- mice (not shown).

Based on the increased concentrations of probasin in the functional secretory epithelium of prostates of Stat5a-null mice and the typical morphology of the affected acini with detached epithelial cells embedded in coagulated secretory material within the lumens, we propose that increased secretion, possibly associated with defective cell-matrix attachment, could be the principal cause of the loss of normal tissue architecture and integrity of prostates of Stat5a-null mice.

\section{Circulating Levels of Testosterone and PRL are Normal in Stat5a-Null Male Mice}

Prostate secretory function and probasin expression are sensitive to changes in circulating testosterone and PRL (Cunha et al, 1987; Rui et al, 1985). We therefore examined serum levels of these hormones in Stat5a-deficient male mice. Specific radioimmunoassays (RIA) demonstrated that both testosterone and PRL levels were normal in Stat5a-knockout mice. Consistent with normal androgen levels, testicular weights (Table 1) and the weights and morphology of seminal vesicles (not shown) were not affected by Stat5a-deficiency. The finding of normal weight and morphology of seminal vesicles further demonstrated that the effect of Stat5a-deficiency on the prostate was selective and did not affect all of the male accessory reproductive organs.

\section{Reduced Expression of PRL Receptors in Prostate Epithelium of Stat5a-Null Mice}

Loss of Stat5a may directly influence the expression levels of genes that are active upstream or downstream of this transcription factor. A functional Stat5response element was recently described in the promoter of the $P R L$ receptor gene, implicating Stat5a as a direct positive regulator of $P R L$ receptor expression (Galsgaard et al, 1999). This is also consistent with $\mathrm{PRL}$-induced up-regulation of PRL receptors in prostate tissue (Rui et al, 1986). We therefore examined the local expression levels of PRL receptors in the prostates of Stat5a-deficient mice by immunohistochemistry. Immunoreactivity with a specific PRL receptor antibody showed high expression levels in a large number of epithelial cells of prostates of wild-type mice (Fig. 7b), but revealed a consistent and marked reduction of $P R L$ receptor expression in prostates of Stat5a-deficient mice (Fig. 7a). Control sections incubated with isotype-specific mouse monoclonal IgG were negative (Fig. 7c). When quantified by counting, the number of PRL receptor-positive cells was more than three times higher in ventral prostates of Stat5a $+/+$ mice than in prostates of Stat5a $-/-$ mice (Fig. $7 \mathrm{~d} ; p<0.01)$. Thus, it is possible that the prostate phenotype of Stat5a-deficient mice is in part due to reduced $P R L$ receptor levels.

The finding of reduced $P R L$ receptor expression levels in prostate epithelium of Stat5a-deficient mice may suggest a preferential regulation of the $P R L$ receptor gene by Stat5a, because Stat5b levels remained unaffected in prostate. Differences have been described in DNA binding specificities between Stat5a and Stat5b (Boucheron et al, 1998), and Stat5a was reported to be particularly important for regulation of the interleukin-2 receptor- $\alpha$ gene (Nakajima et al, 1997). Our results suggest that Stat5a and/or Stat5bdeficient mice could be useful to assess the physiologic contribution of each of the two homologous 


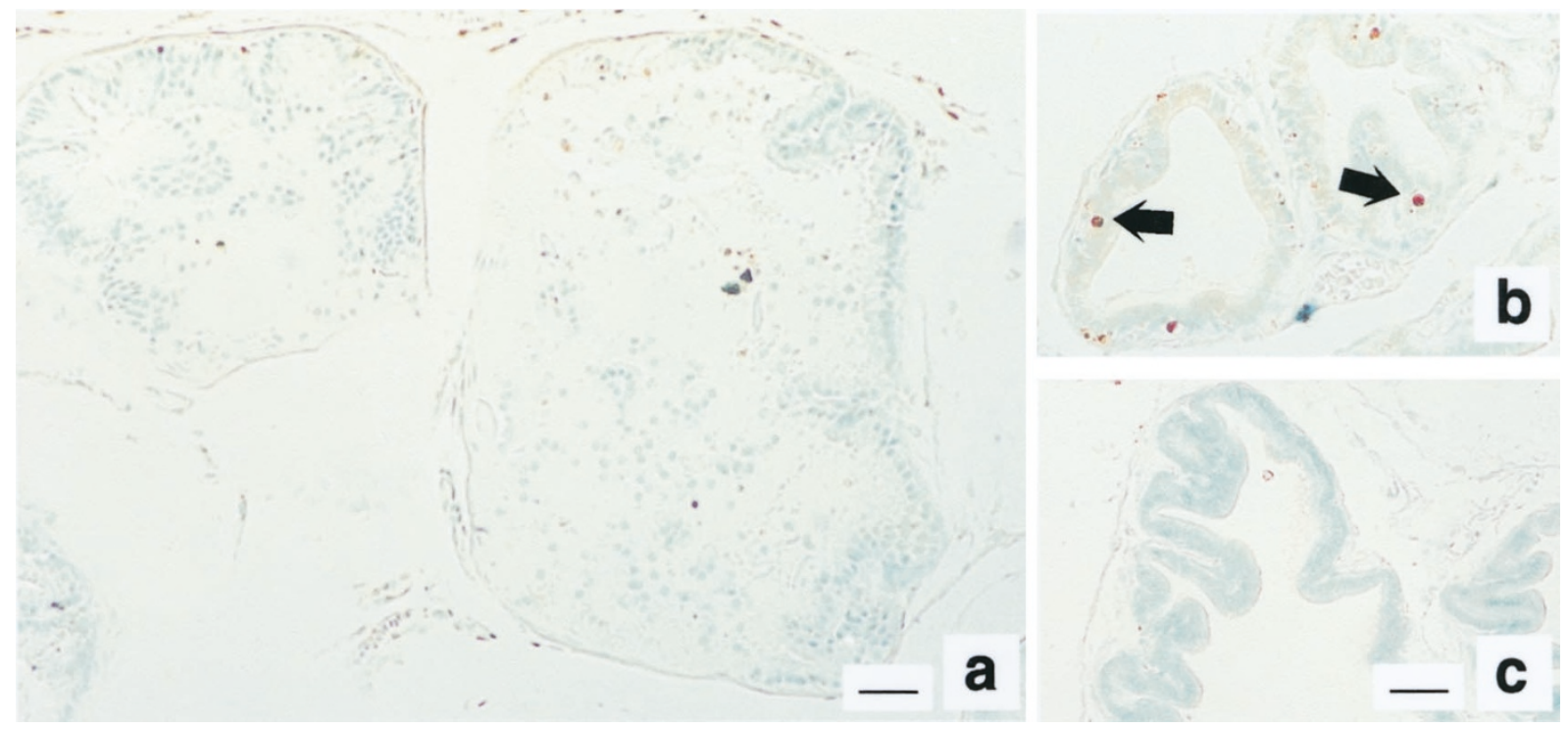

\section{Figure 4.}

DNA fragmentation analysis of ventral prostate of Stat5a-null mice. a) In situ end-labeling assay of fragmented DNA showed that only a small fraction of desquamated epithelial cells within cystic acini of prostates of Stat5a $-/-$ mice were undergoing apoptosis. Bar $=33 \mu \mathrm{m}$. b) Positive control sections of ventral prostate from castrated rats that had been maintained for seven days without androgen substitution, showing distinctly positive immunoreactivity in apoptotic epithelial cells (arrows). On the contrary, ventral prostates from castrated rats receiving androgen substitution for seven days showed no DNA-fragmentation (c), (negative control). b, c: bar $=104 \mu \mathrm{m}$. Sections were counterstained with methyl green.

transcription factors on $P R L$ receptor gene expression in the prostate as well as in other organs. The observed reduction in PRL receptor expression in prostates of male Stat5a-deficient mice also raises the issue of whether $\mathrm{PRL}$ receptor down-regulation contributes to the mammary phenotype of female mice.

\section{No Alterations of PRL-Activated Signal Transduction Molecules in Prostates of Stat5a-Null Mice}

We next examined whether signaling proteins downstream of $\mathrm{PRL}$ receptors were affected in Stat5adeficient mice. In the mammary gland, Stat5a deficiency was paralleled by a reduction in the activation of Stat5b (Liu et al, 1997). This combined reduction of two homologous transcription factors might amplify the phenotypic expression of Stat5a deficiency observed in the mammary gland. It was therefore relevant to compare the levels of Stat5b in prostates of Stat5a-deficient mice with those in prostates of wildtype mice. First, consistent with accurate genotyping of individual mice, immunoblotting for Stat5a protein in extracts representing pooled tissue $(n=4)$ verified that there was no Stat5a in prostates of Stat5a-null mice (Fig. 8a). However, levels of Stat5b in prostates of Stat5a-null mice were normal, in contrast to the reduced Stat5b levels observed in mammary glands. This lack of effect of Stat5a deficiency on Stat5b expression in prostates was established both by immunoblotting of immunoprecipitation-enriched Stat5b (Fig. 8a), and by direct immunoblotting of total proteins from tissue homogenates (Fig. 8b). Likewise, levels of Stat1 and Stat3, other Stat transcription factors that can be activated by PRL (DaSilva et al, 1996; Yamashita et al, 1999), were also unchanged in prostates of Stat5a-deficient mice (Fig. 8c).
There are currently no reports on Stat5a activation by PRL or other cytokines in prostate. However, our observations indicated that Stat5a was indeed constitutively activated in prostates of wild-type mice, as measured by phosphorylation of tyrosine Y694 (Fig. 9a). This phosphorylated tyrosine residue causes Stat5a to dimerize, translocate from the cytoplasm to the nucleus, and bind to DNA. Stat5b was constitutively tyrosine phosphorylated similarly both in Stat5adeficient and wild-type mice (Fig. 9a). In contrast, neither Stat5a nor Stat5b were phosphorylated on serine residues S725 or S730, respectively (Fig. 9b), which, when phosphorylated, may have an inhibitory effect on transcriptional regulation (Yamashita $\mathrm{H}$, Erwin RA, Harmon G, Kirken RA, Rui $H$, unpublished data).

It will be of interest to determine whether prostate morphology is more severely affected in prostates of mice deficient in both Stat5a and the homologous Stat5b, because the more extensive mammary gland phenotype of Stat5a-deficient mice was associated with a concomitant reduction of Stat $5 b$, which remained normal in prostates.

Nonetheless, expression and constitutive tyrosine phosphorylation of Stat5a in prostates of wild-type animals supported the notion of a direct role of Stat5a in mouse prostate. Parallel studies of rats have shown that Stat5a is also expressed and activated in ventral prostates of this species (Ahonen TJ, Rui H, Nevalainen MT, unpublished data), further supporting a general role for Stat5a in prostate epithelium.

The mitogen-activated protein kinases (MAPK) ERK1 and ERK2 may be indirectly involved in regulation of Stat5a serine phosphorylation (Yamashita et al, 1998), and are stimulated by prolactin (Das and 

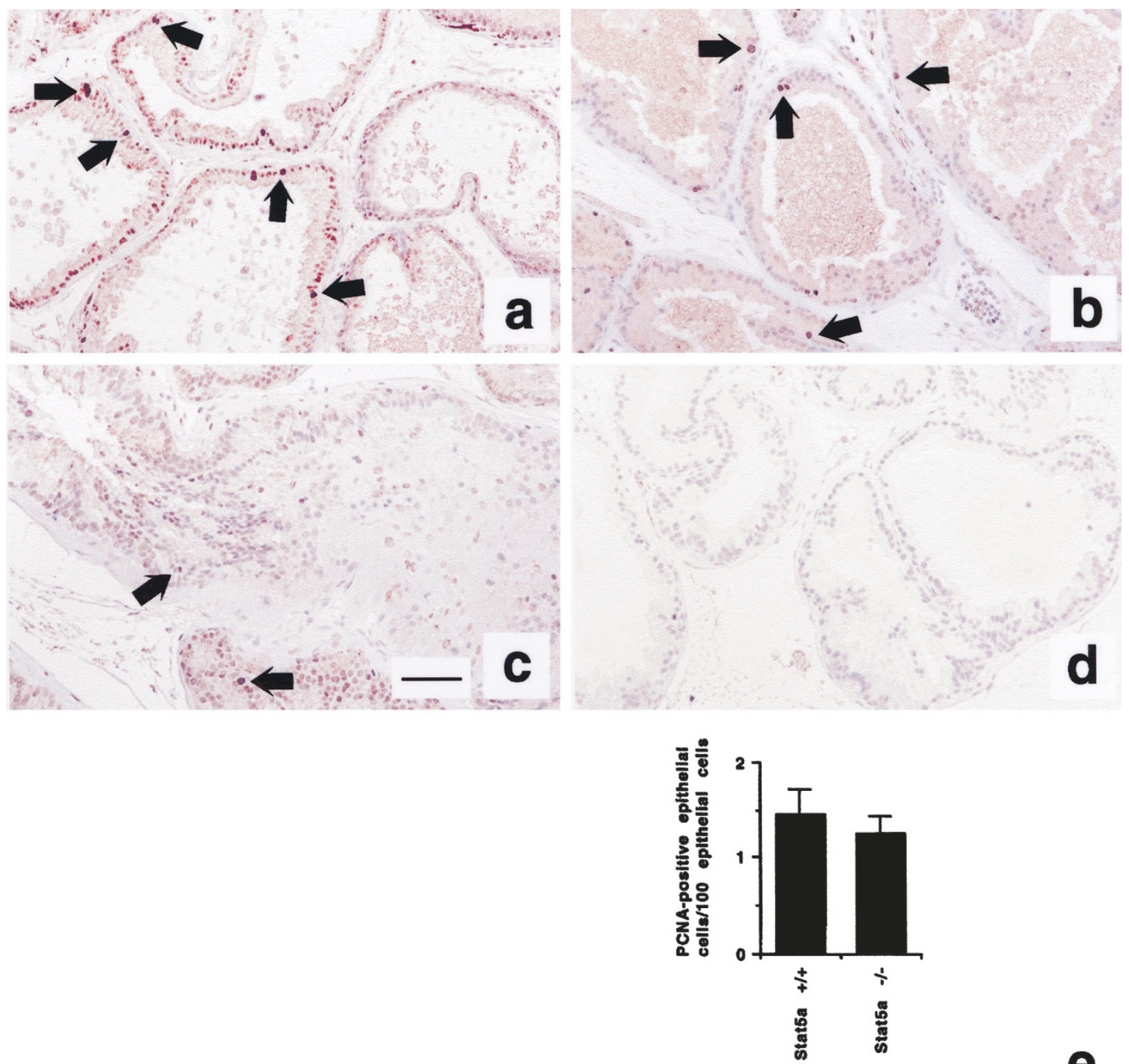

\section{Figure 5.}

Proliferative activity of epithelial cells in ventral prostates of Stat5a-null and wild-type mice. Immunohistochemistry of paraffin-embedded sections of ventral prostates of Stat5a $-I-(a, c)$ and Stat5a $+/+$ (b) mice for a monoclonal anti-proliferating cell nuclear antigen (PCNA) antibody. Of Stat5a-null mice areas of prostates with normal glandular epithelium (a) and epithelium with cystic changes (c) are shown. Biotin-streptavidin amplified peroxidase-antiperoxidase immunodetection showed intensive immunoreactivity in the nuclei of prostate epithelial cells (arrows) (a, b, c). IgG1 was used for control sections (d). a, b, c, d: bar $=68 \mu \mathrm{m}$. e) PCNA-immunoreactive prostate epithelial cells with dark-brown nuclear immunoreactivity were counted per 100 epithelial cells from a total of 63 microscopic fields of Stat5a $+/+(n=8)$ and 66 microscopic fields of Stat5a $-/-(n=7)$ mice. Columns represent means \pm SEM.

Vonderhaar, 1996; Rao et al, 1995). ERK1 and ERK2 were constitutively activated to an equal extent in prostates of Stat5a $-/-$ and Stat5a $+/+$ mice, as assessed by immunoblotting for active ERK1 and ERK2 (Fig. 9c). Collectively, we detected no alterations in expression or activation state of several candidate PRL-regulated transduction molecules other than $P R L$ receptors in prostates of Stat5adeficient mice.

\section{Similar Levels of Local PRL Immunoreactivity in Prostates of Stat5a -/- and Stat5a +/+ Mice}

We have previously described the local production of $\mathrm{PRL}$ or an immunoreactive PRL-like protein in rat and human prostate, possibly operating in an autocrine loop (Nevalainen et al, 1997a, 1997b). To clarify potential alterations in the expression of components of the PRL/PRL receptor/Stat5 signaling axis in prostates of Stat5a-null mice, we examined the levels of PRL immunoreactivity. As presented in Figure 10a and b, marked and specific immunoreactivity was observed with an antibody to PRL, demonstrating that immunoreactive PRL is also present in the epithelium of mouse prostate. However, in contrast to PRL receptor levels, there was no difference in immunoreactivity between wild-type and Stat5a -/- mice. The antiserum was specific, because normal rabbit serum showed no immunoreactivity (Fig. 10d and e) and rat pituitary was strongly immunoreactive (Fig. 10c). On 


\section{Anti-Probasin Immunoblotting:}

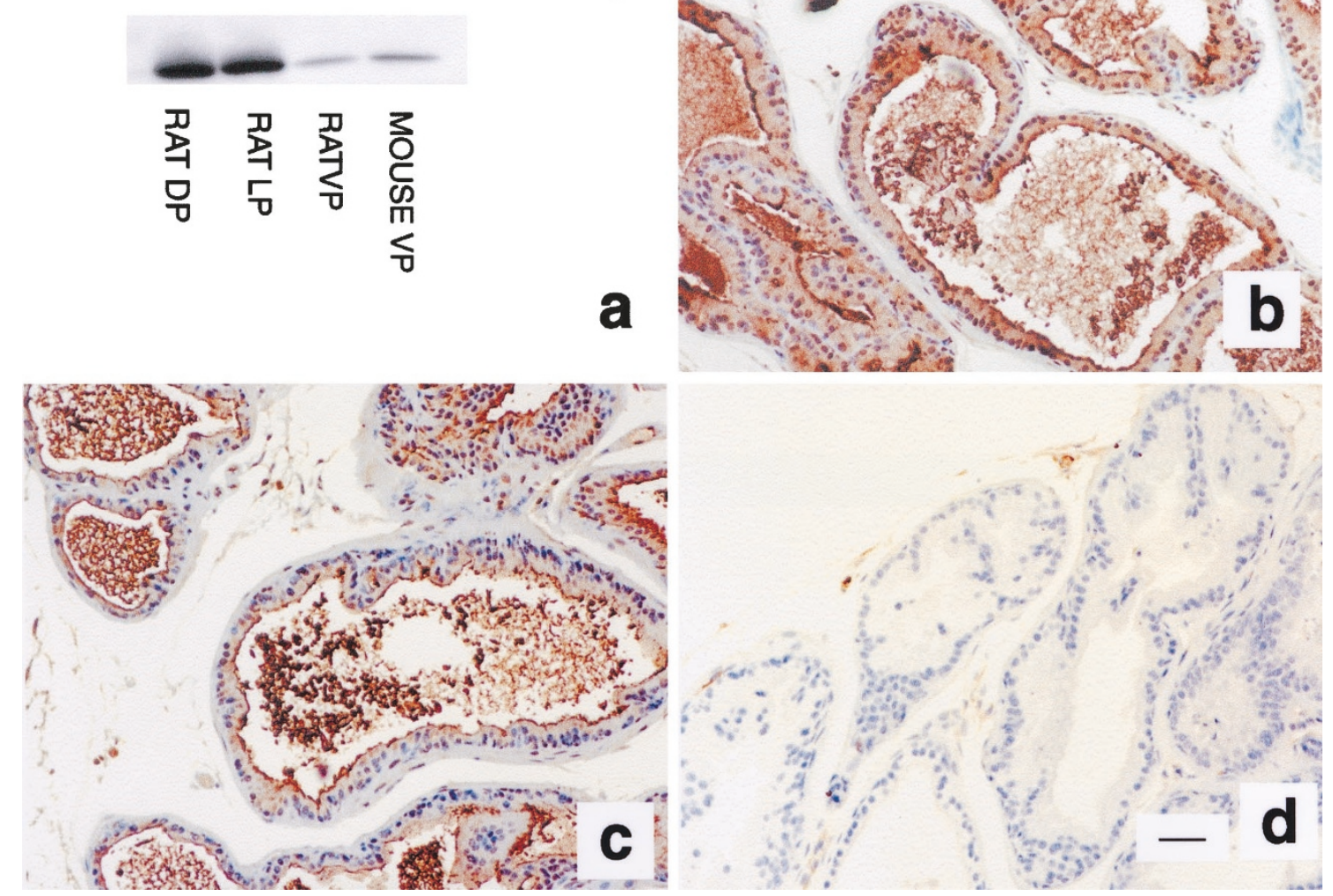

\section{Figure 6.}

Increased levels of prostate-specific secretory protein probasin in ventral prostates of Stat5a-null mice. a) Immunoblot analysis confirming the expression of prostate-specific secretory protein probasin in mouse (total proteins: $20 \mu \mathrm{g})$ and rat $(20 \mu \mathrm{g})$ ventral prostate in addition to rat dorsal $(1 \mu \mathrm{g})$ and rat lateral $(5 \mu \mathrm{g})$ prostate lobes. Immunohistochemistry with polyclonal antibodies to probasin of sections of ventral prostates from Stat5a $-/-$ (b) and Stat5a $+/+$ (c) mice showed increased levels of immunoreactivity in epithelial cells as well as in acinar lumens of prostates of Stat5a $-/-$ mice. Normal rabbit serum was used for control sections (d). $B a r=42 \mu \mathrm{m}$.

Table 1. Age, Serum-Testosterone, Serum-PRL, and Weight of Testes of Stat5a Knockout and Wild-Type Mice

\begin{tabular}{lcc}
\hline & Stat5a $-/-$ & Stat5a $+/+$ \\
\hline Age (months) & $7.9 \pm 0.72$ & $8.5 \pm 0.62$ \\
S-testosterone (ng/ml) & $4.8 \pm 1.05$ & $3.2 \pm 1.13$ \\
S-PRL (ng/ml) & $6.1 \pm 1.1$ & $7.3 \pm 1.8$ \\
Testicular weight $(\mathrm{g})$ & $0.12 \pm 0.004$ & $0.12 \pm 0.008$ \\
\hline
\end{tabular}

Values are means \pm SEM.

the other hand, there was no immunodetectable growth hormone (GH) in the epithelium of mouse prostates (Fig. $10 f$ and g), suggesting that anterior pituitary hormones are not indiscriminately expressed in prostate. This is important because GH activates Stat5 in target tissues (Choi and Waxman, 1999;Waxman et al, 1995), and GH receptors are present in rodent prostate (Reiter et al, 1995a, 1995b) and may mediate growth-regulatory effects (Colao et al, 1999; Wennbo et al, 1997). Specificity of the GH antibodies was verified by positive immunoreactivity of rat pituitary (Fig. 10h).
The present study has demonstrated a specific epithelial defect in ventral prostates of mice lacking the Stat5a gene. In addition to the extensive analysis of the ventral prostates, we have carefully examined the morphology and size of the seminal vesicles, and the small dorsal and lateral lobes of mouse prostate. Dorsal and lateral prostate lobes of Stat5a -/seemed normal by histology, and we did not observe similar gross cystic changes as in ventral prostate. However, the tissue available for study of mouse lateral and dorsal lobes is very sparse, thus, the total amounts of tissue examined were not sufficient to exclude more subtle biochemical and functional changes in these smaller prostate subcompartments. In addition, thus far we have not observed any general secretory epithelial defects in other glandular organs of Stat5a $-/-$ mice.

Immunohistochemical analysis of probasin suggested that local concentrations of this prostatespecific secretory protein were increased in functional epithelial cells of prostates of Stat $5 a-/-$ mice. Future work will address whether other secretory markers are also upregulated or whether there is a selective upregulation of some, but not all, prostatic secretory 


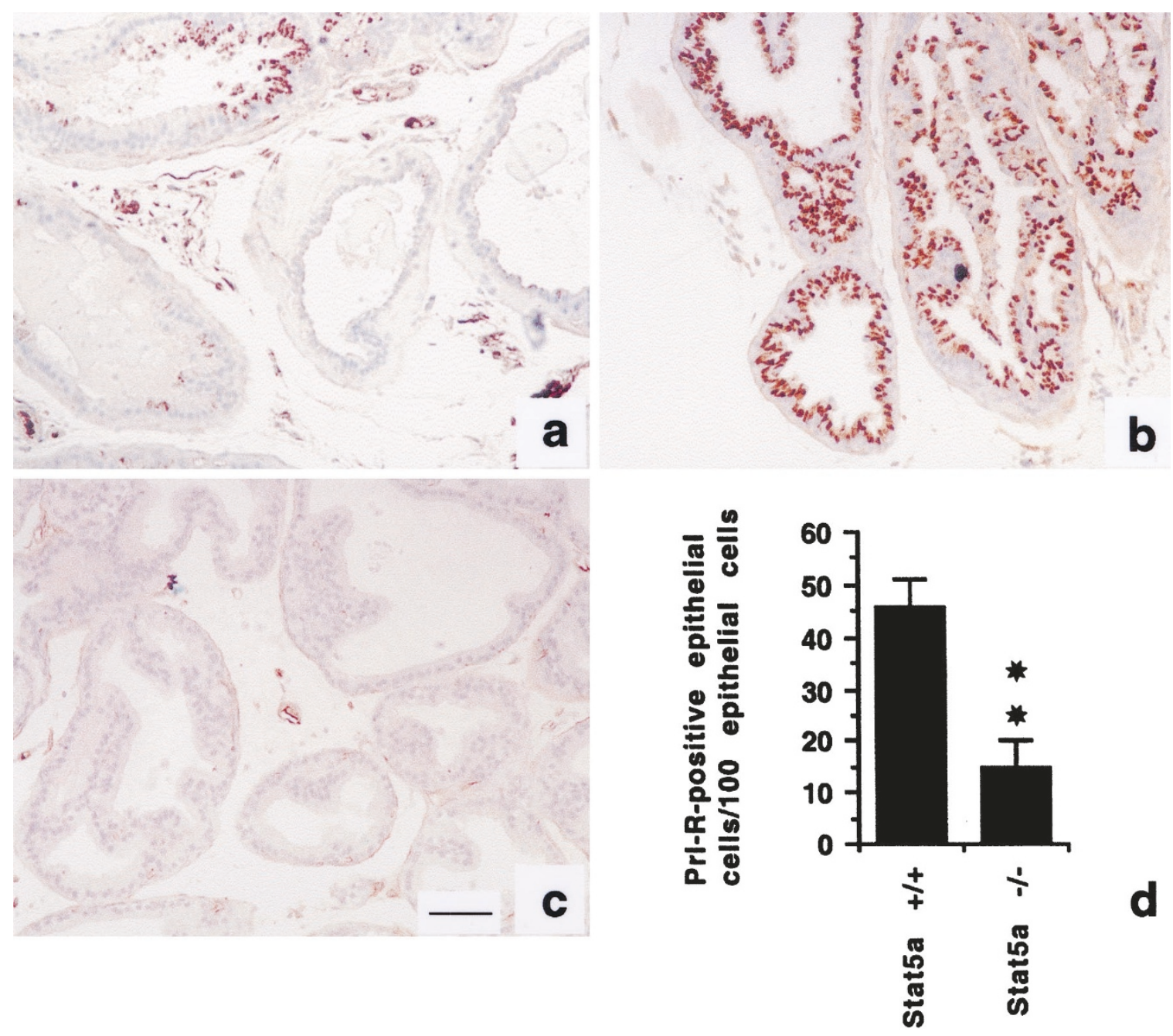

\section{Figure 7.}

Immunohistochemistry showing decreased levels of prolactin (PRL) receptor in ventral prostates of Stat5a-null mice. Immunohistochemistry in sections of ventral prostates of Stat5a $-/-(n=5)$ and Stat5a $+/+(n=10)$ mice with a specific monoclonal antibody to rat PRL receptor $(\mathrm{a}, \mathrm{b})$ and counterstained with hematoxylin. IgG1 was used for control sections (c). Bar, $50 \mu \mathrm{m}$. d) PRL receptor-positive epithelial cells were counted in each section and expressed per 100 epithelial cells. Columns represent means \pm SEM. The data were analyzed with Mann-Whitney's nonparametric rank test $\left({ }^{* *}, p<0.01\right.$ versus Stat5a $\left.+/+\right)$.

products. The observed shedding and desquamation of epithelial cells associated with glandular cyst formation in ventral prostates of Stat5a -/- mice did not correlate with any evidence of an underlying defect involving increased epithelial cell proliferation or increased rates of apoptosis. As a possible explanation, we therefore favored a mechanism of cyst formation that could be secondary to increased secretion, localized secretory retention, and congestion.

It remains mechanistically unclear why selective Stat5a deficiency or an associated imbalance in PRL signal transduction would be associated with increased levels of secretory probasin. In fact, PRL generally stimulates differentiation and secretory function of rodent prostates (Costello and Franklin 1994; Rui et al, 1985). Further knowledge of regulatory targets of the Stat5a transcription factor and insight into the role of individual signal transduction pathways downstream of PRL receptors in the prostate may clarify this apparent paradox. Alternatively, because $\mathrm{PRL}$ regulates fluid transport and electrolyte balance in many vertebrates, it is possible that selective loss of Stat5a signaling is accompanied by reduced fluid uptake that results in a more concentrated secretion by prostate epithelial cells.

In summary, the present study demonstrated a distinct morphologic effect of the lack of Stat5a on ventral prostates of mice, characterized by an increased occurrence of cyst formation with disorganization and detachment of prostate epithelial cells. The epithelial change was not associated with altered cell turnover. Instead, the cause of this cystic morphology may be a local congestion due to hypersecretion, as supported by increased immunoreactivity of the prostate-specific secretory marker, probasin.

Alternatively, a primary defect in epithelial cell attachment in Stat5a-deficient mice may give rise to increased rates of cell shedding and cause the observed phenotype. The recently established connection between PRL receptors and the focal adhesion kinase pathway in mammary cells (Canbay et al, 1997) may also exist in prostate. Examination of the effect of 


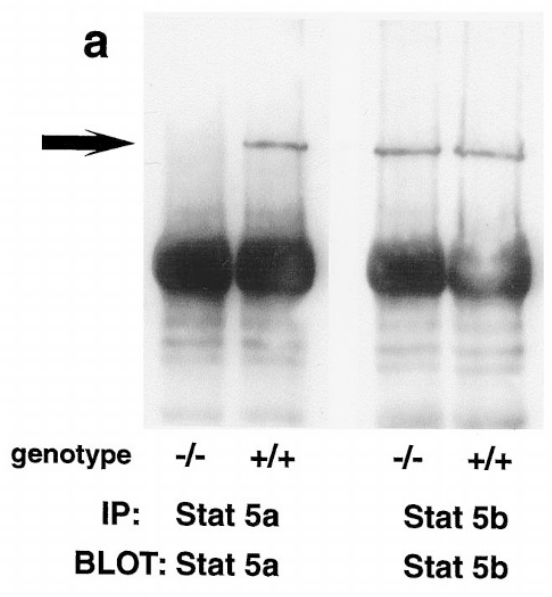

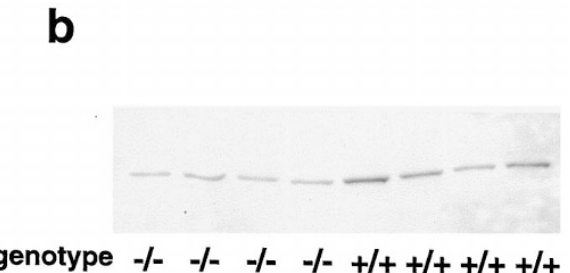

Total protein $20 \mathrm{ug}$

\section{BLOT: Stat 5 b}

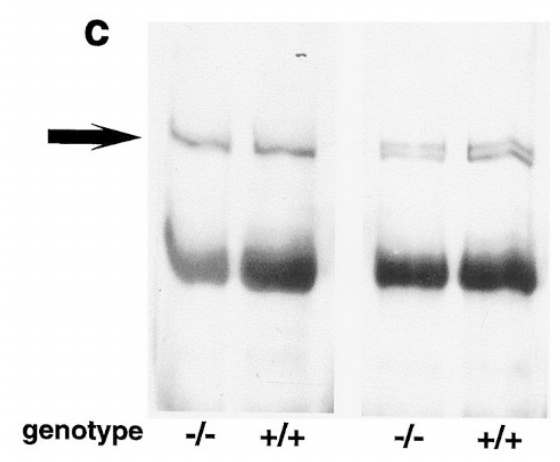

\section{IP: Stat 3 Stat 1}

\section{BLOT: Stat $3 \quad$ Stat 1}

\section{Figure 8.}

Expression of Stat5a, Stat5b, Stat3, and Stat1 in ventral prostates of Stat5a-knockout mice. Western blot analysis of proteins from tissue homogenates of prostates from Stat5a - /- and Stat5a +/+ mice immunoprecipitated with antisera specific to Stat5a (a), Stat5b (a), Stat3 (c), and Stat1 (c), and immunoblotted with antibodies to individual Stats as indicated. b) Unaltered expression of Stat5b in Stat5a-null mice was verified by blotting $20 \mu \mathrm{g}$ of total proteins of prostate tissues of Stat5a $-/-$ and Stat5a $+/+$ mice directly with a specific anti-Stat5b antiserum.

reduced $P R L$ receptor levels on focal adhesion kinase activation and integrin signaling in prostate of Stat5adeficient mice may therefore be the subject of future study.

\section{Materials and Methods}

\section{Animals}

The generation of Stat5a knockout mice has been described previously (Liu et al, 1997). Male mice ranging in age from 4 to 16 months (Stat5a $+/+, n=$ 29; Stat5a $-1-, n=24$ ) were killed by decapitation, and ventral prostates were dissected for investigation. Testes (Stat5a $+/+, n=7$; Stat5a $-/-, n=8$ ) and seminal vesicles were weighed. The genotypes of young mice were determined by PCR analysis of genomic DNA, and the genotype of each animal was verified by a second analysis post mortem. In short, genomic DNA was extracted from an approximately 0.5-cm piece of tail by standard phenol/chloroform extraction from $\mathrm{NaOH}$-treated tissue. PCR was performed on the DNA samples using two pairs of primers. One pair of primers, Neo1 (5'-AGAGGCTATTCGGCTATGACTG-3') and Neo2 (5'-TTCGTCCAGATCATTCTGATC-3'), derived from the neo gene, amplified a $400 \mathrm{bp}$ fragment characteristic to the null allele. A second pair of primers, M15 (5'-TGTCCCGTGTCAGGCCGTGG-3') and 776 (5'-GTCAGGAGCCGTCAGAAGCC-3'), derived from the second noncoding exon and the first coding exon, respectively, amplified a 150 bp fragment of the wild-type allele. Wild-type offspring produced only the $150 \mathrm{bp}$ fragment, homozygous null mice produced only the $400 \mathrm{bp}$ fragment, and heterozygous animals produced both fragments.

\section{Hormone Assays}

Blood samples were obtained by cardiac puncture. Serum PRL (Stat5a $+/+, n=12 ;$ Stat5a $-/-, n=5$ ) and testosterone (Stat5a $+/+, n=8$; Stat5a $-/-, n=$ 8) levels were determined by RIA as described previously (Chandrashekar et al, 1988). Mouse PRL reference preparation and mouse PRL antiserum gener- 

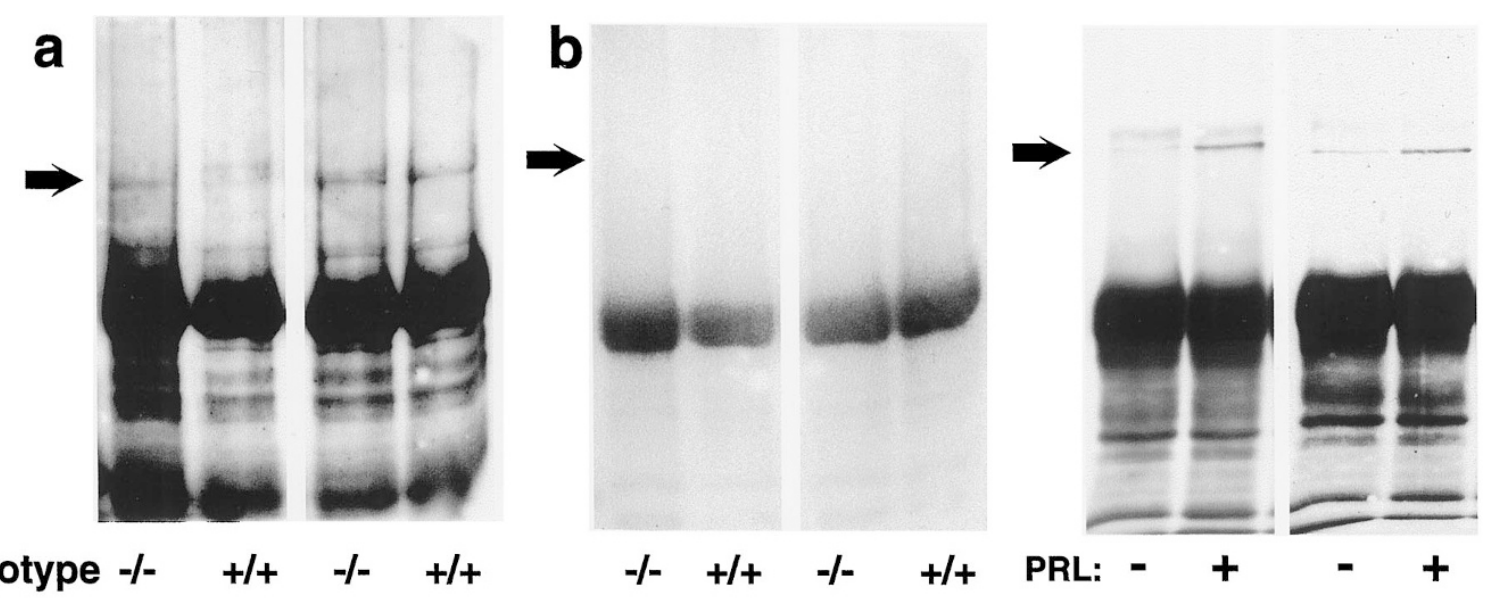

genotype $-/-\quad+/+\quad-/-\quad+/+$

$-1-+1+\quad-1-\quad+1+$

PRL:

\section{IP: Stat 5a Stat 5b IP: Stat 5a Stat 5b IP: Stat5a Stat5b BLOT: anti-pTyr BLOT: anti-pSer BLOT: anti-pSer}
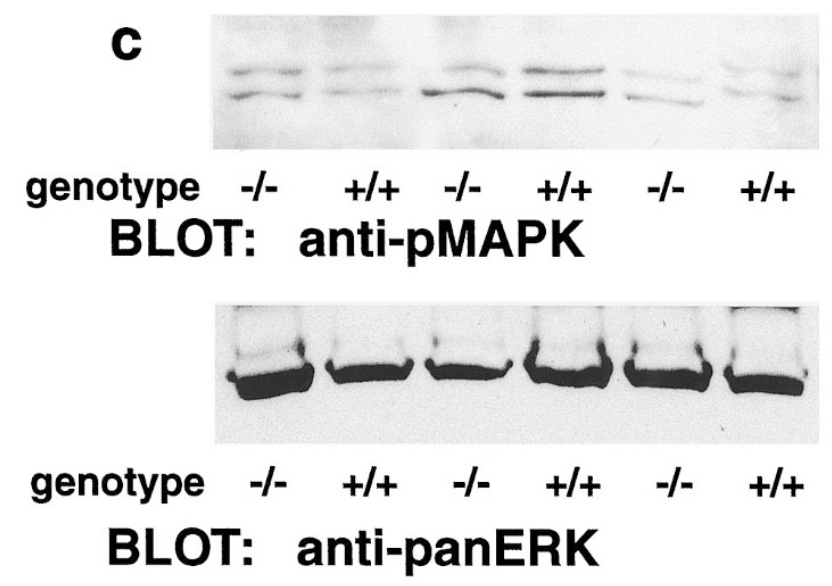

Figure 9.

Activation of Stat5a, Stat5b, and mitogen-activated protein kinases (MAPK) in ventral prostates of wild-type and Stat5a-null mice. Total tissue homogenates (1.5 mg protein) of ventral prostates of Stat5a $+/+$ and Stat5a $-/-$ mice were immunoprecipitated with anti-Stat5a and anti-Stat5b antisera and blotted for phophotyrosine (anti-pTyr) (a) or site-specific anti-Stat5a/b-phosphoserine (anti-pS725/730). Immunoprecipitation of Stat5a and Stat5b from Nb2 cells with $(+)$ or without $(-)$ PRL-stimulation are included as positive controls for serine phosphorylation of Stat5 (b). In parallel, $25 \mu \mathrm{g}$ of total proteins from ventral prostates of Stat5a $-/-$ and Stat5a $+/+$ mice were immunoblotted with antibodies to phosphorylated MAPK (anti-pMAPK) (c, upper panel). Reblot of the stripped samples with anti-panERK antibodies (c, lower panel).

ously provided by Dr. A. F. Parlow, National Pituitary Hormone Program, were used in the PRL assay. Briefly, all serum samples were measured starting on the same day, using reference preparation, antiserum, and repurified hormone trace diluted on the same day. The sensitivity of this assay was $0.1 \mathrm{ng} / \mathrm{tube}$, and the intra-assay coefficient of variation was $2.7 \%$. Serum testosterone levels were determined using commercial solid-phase RIA kits (DPC, Los Angeles, California). The sensitivity of the testosterone assay was 10 $\mathrm{pg} /$ tube, with mean intra-assay coefficient of variation of less than $4 \%$.

\section{Morphology}

For morphologic evaluation, ventral prostates were fixed in either $10 \%$ phosphate-buffered formalin or
Bouin's fixative for 16 hours and embedded in paraffin. Serial $7 \mu \mathrm{m}$-thick sections were cut and stained with hematoxylin and eosin. To quantify the relative number of acini with cystic change, the affected acini were counted and expressed as the percentage of the total number of acini in histological sections taken from 2 different levels of ventral prostates of Stat5a knockout $(n=17)$ and wild-type $(n=14)$ mice.

\section{Immunohistochemistry}

After deparaffination and rehydration of formalin-fixed tissue in graded alcohol, sections for immunohistochemistry of actin, PRL receptor, PRL, and GH were subjected to pretreatment with pepsin (EK 000-5K; BioGenex Laboratories, San Ramon, California) for 5 minutes at $37^{\circ} \mathrm{C}$ to unmask antigen epitopes. Sec- 

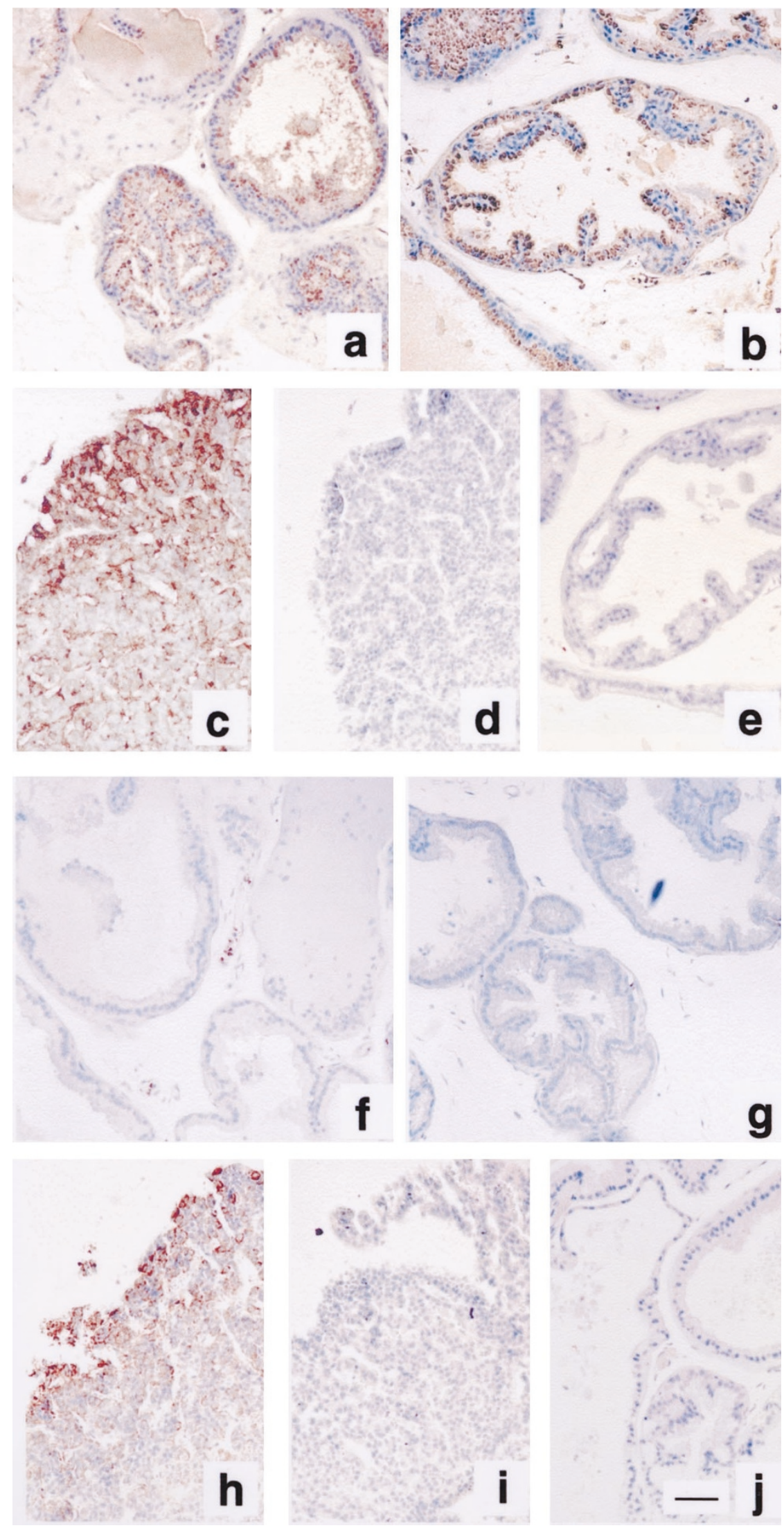

Figure 10.

PRL and growth hormone (GH) protein expression in ventral prostates of Stat5a-knockout and wild-type mice. Immunoreactivity in sections of ventral prostates of Stat5a $-/$ - and Stat5a $+/+$ mice for a polyclonal antibody to rat PRL $(\mathrm{a}, \mathrm{b})$ or a polyclonal antibody to human $\mathrm{GH}(\mathrm{f}, \mathrm{g})$. Sections of rat pituitary were used as positive controls for PRL (c) and GH expression (h). Normal rabbit serum was used for negative control sections (d, e, i, j). Bar $=52 \mu \mathrm{m}$. 
tions for immunohistochemistry of PCNA and probasin were microwave treated in citrate-based solution (neutral pH) (HK086-5K; BioGenex Laboratories) for antigen retrieval. Endogenous peroxidase activity was blocked by incubating slides in $0.3 \%$ hydrogen peroxide for 10 minutes at room temperature (RT). Nonspecific binding of IgGs was minimized by preincubation in normal goat serum (HK112-5K; BioGenex Laboratories) for 1 hour at RT. Primary antibodies were diluted in 1\% BSA in PBS at the following concentrations: polyclonal anti-actin, 1:800 (A-2066; Sigma, St. Louis, Missouri); $20 \mu \mathrm{g} / \mathrm{ml}$ of monoclonal anti-rPRL receptor T1 (gift from Dr. Paul Kelly, INSERM, Paris, France) (Okamura et al, 1989); polyclonal anti-rPRL, 1:800 (gift from Dr. A. F. Parlow; The National Pituitary Hormone Program); polyclonal antihGH, 1:500 (PU028-UP; BioGenex Laboratories), monoclonal anti-PCNA, 1:8 (MU252-UC; BioGenex Laboratories); and polyclonal anti-probasin, 1:3,000 (gift from Dr. R. Matusik, Vanderbilt University, Nashville, Tennessee) (Spence et al, 1989). Antigenantibody complexes were detected using biotinylated goat anti-rabbit or anti-mouse secondary antibodies (AD000-5R and AD000-5M, respectively; BioGenex Laboratories) followed by streptavidin-horseradishperoxidase complex. 3,3-[prime] diaminobenzidine was used as the chromogen and Mayer hematoxylin as a counterstain. For controls, normal rabbit serum, purified polyclonal rabbit IgG, or subtype-specific mouse IgG were used as appropriate.

\section{In Situ End-Labeling}

For the DNA fragmentation assay (Oncogene Research Products, Calbiochem, Cambridge, Massachusetts), sections were deparaffinized and rehydrated in graded alcohol and subjected to Proteinase $\mathrm{K}$ treatment for 20 minutes at $\mathrm{RT}$ to enhance the sensitivity of the DNA end-labeling. Endogenous peroxidase activity was blocked by incubating the slides in $0.3 \%$ hydrogen peroxide in water for 10 minutes at RT. Biotin-labeled deoxynucleotides were catalytically added to $3^{\prime}-\mathrm{OH}$ ends of double- or single-stranded DNA by terminal deoxynucleotidyl transferase during a 90 minute $37^{\circ} \mathrm{C}$ incubation. Nucleotides incorporated into fragmented DNA were detected after incubation with streptavidin-conjugated horseradish peroxidase (30 minutes at RT) followed by visualization with diaminobenzidine (10 minutes at RT) as the chromogen. Methyl green was used as a counterstain. Ventral prostate tissues from castrated rats that had been maintained for seven days without or with androgen substitution were used as positive and negative controls, respectively, for the DNA fragmentation assay.

\section{Solubilization of Proteins, Immunoprecipitations, and Immunoblotting}

Prostate tissues were homogenized with an Ultraturrax homogenizer (Janke \& Kunkel GmbH \& Co., IKA Labortechnik, Staufen, Germany) in lysis buffer $(1 \mathrm{~g} / 5$ $\mathrm{ml}$ ) containing $10 \mathrm{~mm}$ Tris- $\mathrm{HCl}, \mathrm{pH}$ 7.6, 5 mm EDTA, 50 $\mathrm{mm} \mathrm{NaCl}, 30 \mathrm{~mm}$ sodium pyrophosphate, $50 \mathrm{~mm}$ sodium fluoride, $1 \mathrm{~mm}$ sodium orthovanadate, $1 \%$ Triton X-100, $1 \mathrm{~mm}$ phenylmethylsulphonylfluoride, 5 $\mu \mathrm{g} / \mathrm{ml}$ aprotinin, $1 \mu \mathrm{g} / \mathrm{ml}$ pepstatinA, and $2 \mu \mathrm{g} / \mathrm{ml}$ leupeptin. Tissue homogenates were rotated endover-end at $4^{\circ} \mathrm{C}$ for 60 minutes, and insoluble material was pelleted at $12,000 \times \mathrm{g}$ for 30 minutes at $4^{\circ} \mathrm{C}$. The protein concentrations of clarified tissue lysates were determined by a simplified Bradford method (5000006; BioRad Laboratories, Hercules, California). One milliliter of lysate containing $1.5 \mathrm{mg}$ of total protein was used for immunoprecipitation for 3 hours at $4^{\circ} \mathrm{C}$ with polyclonal rabbit antisera $(5 \mu \mathrm{l} / \mathrm{ml})$ specific to Stat1 (p84/p91 (E-23) catalog no. sc-346; Santa Cruz Biotechnology, Santa Cruz, California) or to Stat5a, Stat5b, or Stat3, which have been generated as described (Kirken et al, 1997). Cell lysates of Nb2 lymphocytes stimulated with PRL for 15 minutes were used as the positive control for serine phosphorylation of Stat5 (Yamashita et al, 1998). Antibodies were captured by incubation for 60 minutes with protein A-Sepharose beads (17-0780-01; Pharmacia Biotech Inc., Piscataway, New Jersey), washed 3 times in $1 \mathrm{ml}$ of lysis buffer, and samples were subjected to $7.5 \%$ SDS-PAGE under reducing conditions. For some analyses, 20 to $25 \mu \mathrm{g}$ of total proteins of prostate tissue homogenates were directly separated by $7.5 \%$ SDS-PAGE without preceding immunoprecipitation (immunoblotting of anti-active MAPkinase, Stat5b, anti-actin, and anti-probasin). The proteins were transferred to polyvinylidene difluoride membrane (1PVH 00010; Millipore, Bedford, Massachusetts), using a semidry transfer unit (Multiphor Novablot, Pharmacia Biotech Inc.). After transfer, the blots were incubated overnight at RT in blocking buffer $(0.02 \mathrm{M}$ Tris- $\mathrm{HCl}, \mathrm{pH} 7.6,0.137 \mathrm{M} \mathrm{NaCl}, 1 \%$ bovine serum albumin, and $0.01 \%$ sodium azide) before immunoblotting. Blots were exposed overnight to primary antibodies diluted in blocking buffer at the following concentrations: anti-Stat5a/b-phosphotyrosine,1 $\mu \mathrm{g} / \mathrm{ml}$ (Y694/Y699, catalog no. 05-495; Upstate Biotechnology, Lake Placid, New York); anti-Stat5a/bphosphoserine (anti-pS725/730), 1:5000 (Yamashita et al, 1998); anti-Stat5a, 1:3000 (Kirken et al, 1997); anti-Stat5b, 1:3000 (Kirken et al, 1997); anti-Stat3, 0.1 $\mu \mathrm{g} / \mathrm{ml}$ (S21-120/L2; Transduction Laboratories and Pharmingen, San Diego, California); anti-Stat1, 0.1 $\mu \mathrm{g} / \mathrm{ml}$ (S21-320/L3; Transduction Laboratories and Pharmingen); anti-MAP kinase, 1:5000 (V803A; Promega, Madison, Wisconsin); and anti-panERK, 0.05 $\mu \mathrm{g} / \mathrm{ml}$, 1:5000 (E17-120; Transduction Laboratories and Pharmingen). The blots were incubated three times for 15 minutes in wash buffer $(50 \mathrm{~mm}$ Tris- $\mathrm{HCl}$, $\mathrm{pH}$ 7.6, $200 \mathrm{~mm} \mathrm{NaCl}, 0.25 \%$ Tween 20), incubated for 30 minutes with horseradish peroxidase-conjugated goat antibodies to mouse or rabbit IgG, 1:2000 (M15345 or R14745, respectively; Transduction Laboratories and Pharmingen) in blocking buffer, and washed three times for 15 minutes in wash buffer. The blots were incubated for 1 minute with enhanced chemiluminesence substrate mixture according to the manufacturer's instructions (RPN2106; Amersham 
Pharmacia Biotech, Inc., Piscataway, New Jersey), and exposed to x-ray film (165-1454; Eastman Kodak Company, Rochester, New York).

\section{Statistics}

Mann-Whitney's nonparametric rank test was used to analyze the frequency of cystic change and the number of PRL receptor-positive epithelial cells in Stat5a wild-type and null mice, and the Student's $t$ test was used for the comparison of testosterone and PRL levels (Norusis, 1994).

\section{Acknowledgements}

We would like to thank Dr. R. Matusik (Vanderbilt University, Nashville, Tennessee) for providing the anti-Probasin antibody and Dr. P. Kelly (INSERM U-344, Paris, France) for providing the antirPRLreceptor antibody (T1). Also, the National Institute of Diabetes and Digestive and Kidney Diseases (NIDDK) National Pituitary Hormone Program and Dr. A. F. Parlow (Pituitary Hormone and Antisera Center, Torrance, California) are gratefully acknowledged for providing antibodies and reagents used in the mouse PRL RIA.

\section{References}

Ahonen TJ, Harkonen PL, Laine J, Rui H, Martikainen PM, and Nevalainen MT (1999). Prolactin is a survival factor for androgen-deprived rat dorsal and lateral prostate epithelium in organ culture. Endocrinology 140:5412-5421.

Boucheron C, Dumon S, Santos SC, Moriggl R, Hennighausen L, Gisselbrecht S, and Gouilleux F (1998). A single amino acid in the DNA binding regions of Stat5A and Stat5B confers distinct DNA binding specificities. J Biol Chem 273: 33936-33941.

Canbay E, Norman M, Kilic E, Goffin V, and Zachary I (1997). Prolactin stimulates JAK2 and focal adhesion kinase pathways in human breast carcinoma T47D cells. Biochem $\mathrm{J}$ 324:231-236.

Chandrashekar V, Bartke A, and Wagner TE (1988). Endogenous human growth hormone $(\mathrm{GH})$ modulates the effect of gonadotropin-releasing hormone on pituitary function and the gonadotropin response to the negative feedback effect of testosterone in adult male transgenic mice bearing human GH gene. Endocrinology 123:2717-2722.

Choi HK and Waxman DJ (1999). Growth hormone, but not prolactin, maintains low-level activation of Stat5a and Stat5b in female rat liver. Endocrinology 140:5126-5135.

Colao A, Marzullo P, Spiezia S, Ferone D, Giaccio A, Cerbone G, Pivonello R, Di Somma C, and Lombardi G (1999). Effect of growth hormone $(\mathrm{GH})$ and insulin-like growth factor I on prostate diseases: An ultrasonographic and endocrine study in acromegaly, GH deficiency, and healthy subjects. J Clin Endocrinol Metab 84:1986-1991.

Costello LC and Franklin RB (1994). Effects of prolactin on the prostate. Prostate 24:162-166.

Cunha CR, Donjacour AA, Cooke PS, Mee S, Bigsby RM, Higgins SJ, and Sugimura $Y$ (1987). The endocrinology and developmental biology of the prostate. Endocrine Rev 8:338361.
Das R and Vonderhaar BK (1996). Activation of raf-1, MEK, and MAP kinase in prolactin responsive mammary cells. Breast Cancer Res Treat 40:141-149.

DaSilva L, Rui H, Erwin RA, Howard OM, Kirken RA, Malabarba MG, Hackett RH, Larner AC, and Farrar WL (1996). Prolactin recruits Stat1, Stat3 and Stat5 independent of conserved receptor tyrosines TYR402, TYR479, TYR515 and TYR580. Mol Cell Endocrinol 117:131-140.

Darnell JE (1997). STATs and gene regulation. Science 277: 1630-1635.

Dodd JG, Kreis C, Sheppard PC, Hamel A, and Matusik RJ (1986). Effect of androgens on mRNA for a secretory protein of rat dorsolateral prostate and seminal vesicle. Mol Cell Endocrinol 47:191-200.

Frisch SM and Francis H (1994). Disruption of epithelial cell-matrix interactions induces apoptosis. J Cell Biol 124: 619-626.

Frisch SM, Vuori K, Ruoslahti E, and Chan-Hui PY (1996). Control of adhesion-dependent cell survival by focal adhesion kinase. J Cell Biol 134:793-799.

Galsgaard ED, Nielsen JH, and Moldrup A (1999). Regulation of prolactin receptor (PRLR) gene expression in insulinproducing cells. J Biol Chem 274:18686-18692.

Gouilleux F, Moritz D, Humar M, Moriggl R, Berchtold S, and Groner B (1994). Prolactin induces phosphorylation of Tyr694 of Stat5 (MGF), a prerequisite for DNA binding and induction of transcription. EMBO J 12:4361-4369.

Janssen T, Darro F, Petein M, Raviv G, Pasteels JL, Kiss R, and Schulman CC (1996). In vitro characterization of prolactin-induced effects on proliferation in the neoplastic LNCaP, DU145, and PC3 models of the human prostate. Cancer 77:144-149.

Kirken RA, Malabarba MG, Xu J, Liu X, Farrar WL, Hennighausen L, Larner AC, Grimley RM, and Rui H (1997). Prolactin stimulates serine/tyrosine phosphorylation and formation of heterocomplexes of multiple Stat5 isoforms in $\mathrm{Nb} 2$ lymphocytes. J Biol Chem 272:14098-15003.

Liu X, Robinson GW, Gouilleux F, Groner B, and Hennighausen $L$ (1995). Cloning and expression of Stat5 and an additional homologue (Stat5b) involved in prolactin signal transduction in mouse mammary tissue. Proc Natl Acad Sci USA 92:8831-8835.

Liu X, Robinson GW, and Hennighausen L (1996). Activation of Stat5a and Stat5b by tyrosine phosphorylation is tightly linked to mammary gland differentiation. Mol Endocrinol 10:1496-1506.

Liu X, Robinson GW, Wagner KU, Garrett L, Wynshaw-Boris $A$, and Hennighausen $L$ (1997). Stat5a is mandatory for adult mammary gland development and lactogenesis. Genes Dev 11:179-186.

Mostofi FK and Price EB Jr (1973). Tumors of the Prostate. In: Firminger $\mathrm{HI}$, editor. Tumors of the Male Genital System. Washington DC: Armed Forces Institute of Pathology, 182194.

Nakajima H, Liu XW, Wynshaw-Boris A, Rosenthal LA, Imada K, Finbloom DS, Hennighausen L, and Leonard WJ (1997). An indirect effect of Stat5a in IL-2-induced proliferation: A critical role for Stat5a in IL-2-mediated IL-2 receptor alpha chain induction. Immunity 7:691-701. 
Nakamura A, Shirai T, Ogawa K, Wada S, Fujimoto NA, and Ito $N$ (1990). Promoting action of prolactin released from a grafted transplantable pituitary tumor (Mt/F84) on rat prostate carcinogenesis. Cancer Lett 53:151-157.

Nevalainen MT, Martikainen P, Valve EM, Ingleton PM, Nurmi M, and Harkonen PL (1997a). Prolactin receptors are expressed and functioning in human prostate. J Clin Invest 99:618-627.

Nevalainen MT, Valve EM, Ahonen TA, Yagi A, Paranko J, and Harkonen PL (1997b). Androgen-dependent expression of prolactin in rat prostate epithelium in vivo and in organ culture. FASEB J 11:1297-1307.

Nevalainen MT, Valve EM, Ingleton PM, and Härkönen PL (1996). Expression and hormone regulation of prolactin receptors in rat dorsal and lateral prostate. Endocrinology 137:1-11.

Nevalainen MT, Valve EM, Makela SI, Blauer M, Tuohimaa PJ, and Harkonen PL (1991). Estrogen and prolactin regulation of rat dorsal and lateral prostate in organ culture. Endocrinology 129:612-622.

Norusis MJ (1994). SPSS/PC Base Manual, SPSS version 6.1. Chicago: SPSS, Inc.

Okamura H, Zachwieja J, Raguet S, and Kelly PA (1989). Characterization and applications of monoclonal antibodies to the prolactin receptor. Endocrinology 124:2499-2508.

Rao YP, Buckley DJ, and Buckley AR (1995). Rapid activation of mitogen-activated protein kinase and p21ras by prolactin and interleukin 2 in rat $\mathrm{Nb} 2$ node lymphoma cells. Cell Growth Differ 6:1235-1244.

Reiter E, Hennuy B, Bruynix M, Cornet A, Klug M, McNamara M, Closset J, and Hennen G (1999). Effects of pituitary hormones on the prostate. Prostate 38:159-165.

Reiter E, Kecha O, Hennuy B, Lardinois S, Klug M, Bruyninx M, Closset J, and Hennen G (1995a). Growth hormone directly affects the function of the different lobes of the rat prostate. Endocrinology 136:3338-33345.

Reiter E, Lardinois S, Klug M, Sente B, Hennuy B, Bruyninx M, Closset J, and Hennen G (1995b). Androgen-independent effects of prolactin on the different lobes of the immature rat prostate. Mol Cell Endocrinol 112:113-122.

Rui H, Brekke I, Torjesen PA, and Purvis K (1986). Homologous up-regulation of the prolactin receptor in rat prostatic explants. Mol Cell Endocrinol 46:53-57.

Rui H, Haug E, Thomassen Y, and Purvis K (1985). Shortterm effects of prolactin on prostatic function in rats with lisuride-induced hypoprolactinemia. J Reprod Fertil 75:421432.
Russell PJ, Bennett S, and Stricker P (1998). Growth factor involvement in progression of prostate cancer. Clin Chem 44:705-723.

Spence AM, Sheppard PC, Davie JR, Matuo Y, Nishi N, McKeehan WL, Dodd JG, and Matusik RJ (1989). Regulation of a bifunctional mRNA results in synthesis of secreted and nuclear probasin. Proc Natl Acad Sci USA 7843-7847.

Steger RW, Chandrashekar V, Zhao W, Bartke A, and Horseman ND (1998). Neuroendocrine and reproductive functions in male mice with targeted disruption of the prolactin gene. Endocrinology 139:3691-3695.

Steiner MS (1993). Role of peptide growth factors in the prostate: A review. Urology 42:99-110.

Teglund S, McKay C, Schuetz E, van Deursen JM, Stravopodis D, Wang D, Brown M, Bodner S, Grosveld G, and Ihle JN (1998). Stat5a and Stat5b proteins have essential and nonessential, or redundant roles in cytokine responses. Cell 93:841-850.

Udy BG, Towers RP, Snell RG, Wilkins RJ, Park SH, Ram PA, Waxman DJ, and Davey HW (1997). Requirement of Stat5b for sexual dimorphism of body growth rates and liver gene expression. Proc Natl Acad Sci USA 94:7239-7244.

Wakao H, Gouilleux F, and Groner B (1994). Mammary gland factor (MGF) is a novel member of the cytokine regulated transcription factor gene family and confers the prolactin response. EMBO J 13:2182-2191.

Waxman DJ, Ram PA, Park SH, and Choi HK (1995). Intermittent plasma growth hormone triggers tyrosine phosphorylation and nuclear translocation of a liver-expressed Stat5related DNA binding protein. Proposed role as an intracellular regulator of male-specific liver gene transcription. J Biol Chem 270:13262-1327.

Wennbo H, Kindblom J, Isaksson OG, and Tornell J (1997). Transgenic mice overexpressing the prolactin gene develop dramatic enlargement of the prostate gland. Endocrinology 138:4410-4415.

Yamashita H, Xu J, Erwin RA, Farrar WL, Kirken RA, and Rui $H$ (1998). Differential control of the phosphorylation state of proline-juxtaposed serine residues Ser725 of Stat5a and Ser730 of Stat5b in prolactin-sensitive cells. J Biol Chem 273:30218-30224.

Yamashita H, Xu J, Erwin RA, Larner AC, and Rui H (1999). A lymphoma growth inhibitor blocks some but not all prolactinstimulated signaling pathways. J Biol Chem 274:1469914705. 